\title{
Of Wounds and Cracks and Pits: A Reading of Dear Life
}

Christine Berthin

\section{(2) OpenEdition \\ 1 Journals}

Electronic version

URL: https://journals.openedition.org/ces/5072

DOI: $10.4000 /$ ces.5072

ISSN: 2534-6695

Publisher

SEPC (Société d'études des pays du Commonwealth)

\section{Printed version}

Date of publication: 1 April 2015

Number of pages: $79-87$

ISSN: 2270-0633

\section{Electronic reference}

Christine Berthin, "Of Wounds and Cracks and Pits: A Reading of Dear Life", Commonwealth Essays and Studies [Online], 37.2 | 2015, Online since 13 April 2021, connection on 17 July 2021. URL: http:// journals.openedition.org/ces/5072 ; DOI: https://doi.org/10.4000/ces.5072

\section{(c) $($ †) $\ominus$}

Commonwealth Essays and Studies is licensed under a Licence Creative Commons Attribution - Pas d'Utilisation Commerciale - Pas de Modification 4.0 International. 


\section{Of Wounds and Cracks and Pits: A Reading of Dear Life}

This essay focuses on loss and trauma as structuring motifs in several individual stories in Dear Life. They represent privileged moments of access to the Real that disturbs and pierces the smooth surface of ordinary life and reality. But read as a whole, the volume also offers a reflection on the process of healing at the heart of story telling and on the reconstructive work of language that allows life to continue.

There is always a danger in planning to present a "reading" of a collection of stories that were originally published singly, usually in the context of a magazine and that were gathered up in a collection only at a later stage of their life in print. John Updike, in a review of Alice Munro's Selected Stories in 1996, reflecting on the various publishing formats, compared a short story collection, with its "aspiration to coherence and unity," to "a musical album, say Joni Mitchell's Blue," whereas the volume of Selected Stories could only be, to his mind, "the literary (or rather publishing) counterpart to Joni Mitchell's Hits," a "format rather than an art form" (Robson np). Reading a collection of stories like an album, with the sense that there is a tonality, a colour or a tone shared by most of the pieces, is not without artifice. Alice Munro herself protests against the critical assumption that the stories in her collections are linked: "what on earth is this feeling that somehow things have to connect or... have to be part of a larger whole?" (qtd. in Carrington 3) Aware of this pitfall, I will nonetheless take the risk of bringing together some of Dear Life's stories, not with the intention of finding the key to the volume, the intention of the lot, but animated by the belief that, as Ildikó de Papp Carrington puts it, "things do connect and there is a coherent whole, recognizable patterns" in Munro's fiction (4). The texts gathered together in Dear Life undoubtedly form an organic whole and the collection is not a random aggregation of texts. On the contrary, the whole is greater than sum of its parts.

My journey through the "album" is inspired by a quote from "Carried Away" where a character wonders whether the female protagonist of the story of loss and impossible love was "one of those people full of mended cracks that you could only see close up" (Munro, Selected Stories 378). People full of mended cracks form a recognizable pattern in Munro's fiction. In "Train," "Gravel" and "Pride," in particular, hidden wounds, the wounds of loss, trauma, or difference leave their traces in the texts, causing disturbances in the symbolic. There are no wounds without scars, and therefore it is the mending of the cracks, and the traces of the wounds left in the very verbal texture of the stories upon which this reading will focus.

But in Dear Life, which Munro presents as her last collection of stories, the author also revisits her own wounds, in the final part of the collection, the "Finale" or autobiographical section. At the end of Munro's life journey, and at the end of her writing career the issue of whether the mending of cracks ever becomes the healing of wounds and the issue of the power of words on the wounds of life remain vividly acute and pressing. 


\section{The Rawness of Life}

In her famous definition of "what is real" for her, Munro describes writing a story as the compulsive need to create a certain type of structure, build a house around an indescribable feeling. She explains how there is a "black room at the centre of the house with all other rooms leading to and away from it" ("What is Real" 868). Wounds, cracks and pits immediately evoke the core of darkness that inhabits each of her stories, a core of darkness which seems to be the closest equivalent possible of the Lacanian "Real." The Real emerges in reality as that which undermines reality and shatters our symbolic constructions, our sense of being subjects in control of our world. By definition "the real cannot be experienced as such: it is capable of representation or conceptualisation only through the reconstructive or inferential work of the imaginary or symbolic orders" (Elizabeth Grosz 34). What we experience as reality is always symbolized, constituted and structured by symbolic mechanisms. The Real is the menace that all our symbolic constructions try to keep at bay. In order to describe the uneasy relationship between reality and the Real, Slavoj Zizek uses the example of Malevich's painting: The Naked Unframed Icon of my Time, where a white square frames a black hole. Reality is the white frame, a grid imposed on chaos. The black mass at the centre of the picture gives the white background its consistency, but also shows its frailty, as the inscrutable darkness can always overflow and disrupt the limits of the white frame (Zizek 19).

Munro's fiction recurrently rehearses these impossible moments of "encounters with the Real" where reality crumbles, like dark holes uneasily contained in the frame of the white page. Many stories are organised around a traumatic event or its long-term effects. For instance, Corrie's sudden discovery that unbeknown to her she had been paying for her lover's attention for over 20 years leaves her hollow, and opens up a hole in her sense of reality: "A cavity everywhere, most notably in her chest. She makes coffee and doesn't drink it. She ends up in her bedroom once more, and finds that the introduction to the current reality has to be done all over again" "CCorrie," Dear Life 173). Similarly, in "Amundsen," the demise of the subject, left at the altar the day of her "bare-bones wedding" (Dear Life 57) is evoked in terms of flaying. The subject becomes raw, loses her symbolic armour, her protective skin and sense of self: "every turn is like a shearing-off of what was left of [her] life" (63). The image of the body stripped of its skin reduces to shreds our most basic phenomenological relationship to the living body, "which is based on the radical line of separation between the surface of the skin and what lies beneath" (Zizek, "Lamella" 208). ${ }^{1}$ We can only relate to the body as long as we can ignore what lies beneath its smooth surface, underneath the skin. Short fiction seems to be a privileged format for the staging of encounters with the Real beneath the glossy surface of reality. If in the house of fiction all the rooms lead to the black room, the train, in "To Reach Japan" also shows that a core of darkness remains at the heart of all symbolic constructions: Greta's journey to love, poetry, and freedom ends up in the empty space between the carriages "where the banging and swaying reminded you how things were put together in a way that seemed not so inevitable after all" (Dear Life 25). If the carriages are the smooth spaces where stories are told and put together, where fantasies are elaborated and played out and reality is filtered, it is in the gaping

1. Slavoj Zizek reminds us that "one of the definitions of the Lacanian Real is that it is the flayed, skinned body, the palpitation of raw, skinless red flesh" ("Lamella" 208). 
hole between the carriages, on the "clanging metal plates" that Greta, "drained by fear," finds her lost daughter, with her mouth open in silent horror (25).

But there is in Dear Life a very apt symbol or approximation of the Real, which in fact is a key Munrovian topos, both place and concept, metaphor and metonymy: the image of the gravel pit. Gravel is everywhere in the collection, from the pit in the story entitled "Gravel," of course, to the unstable gravel pile that represents the collapse of Nancy's reason in "In Sight of the Lake." Gravel is also what Jackson comes hard on, scraping his shins in "Train."

Gravel pits in Munro's fiction are often the sign of a precarious existence on the edge of town, as in "Floating Bridge" (Hateship) and "Gravel." They are naturally connected to trailers, to homes that are not houses and to drifting, fragile lifestyles. They are also always associated with the looming dangers of death. In "Turkey Season," we encounter a gravel pit of a different sort, but carrying the same symbolic value: a young girl learns how to gut turkeys, "feeling the gravel, in the crop, the cleft between the gullet and the windpipe, her hands plunging in the cavity of the turkey's entrails" (Selected Stories 172). Gravel, an aggregate of small water-worn or compounded stones, neither solid nor liquid, epitomizes the way the Real can always undermine all symbolic constructions: "It was deathly cold in there, in the turkey's dark inside" (172).

Circling around the gravel pit that separates the trailer, a world of free love and illusory return to natural order, from the city with its solid houses, husbands and middle class ideals, "Gravel" is the story of the evisceration of a family, in the narrator's words, and a ghost story in many respects. The ghost of Banquo, in the person of Neal arrives in the newly opened theatre of the little town to trouble family order and seduce the dutiful mother into an alternative lifestyle. But the imaginary alternative he offers is in turn emptied out by Caro's surreptitious moves to revert to the life she had before the usurper arrived. She, more than Neal, is Banquo's ghost in the story, the spoilsport and the bad conscience of her mother. Yet, gradually, it is the spectral presence of the pit that swallows up the fragile world of the trailer. The time frame of the text corresponds to the nine months of the mother's pregnancy, from the move to the trailer to the birth of her third child. In a sinister fashion a parallel is drawn between the womb of the mother filling up with the growing foetus and the shallow pit growing everyday deeper and filling up with melted snow until it becomes not so much a pit as a womb, and not so much a womb as a tomb for Caro who hurls herself at the cold water with the scarf her mother had wound around her neck trailing behind her, like an umbilical cord of sorts (Dear Life 101). When the pit filling with water, the substance of both life and death, is foregrounded as the focal point of the story, its contours, anamorphically, become brutally clear in their lethal potential, blurring the meaningful yet fragile world of the trailer in the background, and turning it into a formless void.

"Pride" offers another version of the Munrovian motif of cracks and wounds where the narrator's physical handicap, his harelip like a black hole in the middle of his face, sets him apart from the community, rendering his access to the symbolic and to social interactions perilous. In "Facing the Ugly: The Case of Frankenstein," Denise Gigante defines ugliness as the difference that our social systems constantly try to repress. The ontological primacy of ugliness links it to the Real that disturbs our comforting sense of reality structured by symbolic mechanisms. Ugliness for Gigante is the brutal fact of existence we try to fend off. It is the mark of the monster, of the un-symbolized at 
the heart of an elaborate symbolic network. Therefore the narrator of "Pride" is long condemned to a life on the margin, outside historical time and space, until the world around him changes, shifting the borders of what is or is not the norm, thus offering grey areas for him to be more or less accepted in the social landscape of the town. Trauma, difference and loss tear the veil of our daily existence and let through a glimpse of inchoate, raw life that interrupts the law-like regulated stringing together of the subject's signifiers. Yet they are necessary moments in the construction of the subject: they derail the balance of the subject's daily life but also serve as the support of that very balance.

\section{Mending the Cracks: Scars in Language and the Reconstructive Work of Telling}

Looking beyond the moment of destabilising pain, I would like to turn to the effects of the wounds in the construction of the subject and to various ways of mending the cracks through language.

As Clement Rosset reminds us, there are two forms of contact with the Real: a rough contact, when we bump into things, or a polished contact, a smooth contact which replaces the presence of things by their reflected counterpart (44). The world of signs is a mirror for and against the world of things. Like a protective layer against the roughness of the edges of things, language turns wounds into scars, creating a certain type of narrative where scars do not simply hide the gaping holes, but also show their traces. A whole range of rhetorical devices may be mobilized to perform the work of scarring, that is to say, of concealing and yet retaining a revealing trace of the cracks in reality.

In "Pride," the narrator's harelip, obsessively present in the text, affects the form as well as the content of his narrative. The accumulation of incomplete, nominal sentences is a constant reminder of his speech impediment, and of the way it has maimed him internally as well as externally. Under the smooth surface of his narrative, the use of clichés is indicative of his status as an outsider: impersonal and bereft of specificity, clichés are not the mark of an individual subject in language. They are, rather, the disembodied, distant babble of the community. Clichés are also, by nature, anachronistic, today's clichés being yesterday's live expressions. As such they betray the narrator's stunted subjective growth, and his inability to fit in the present. His harelip conditions his choice of self-image as a narrator: a bookkeeper by trade, he sees himself as the historian of the town, the guardian of what was transmitted by "word of mouth" (134) and he keeps count of the injuries, humiliations and wounds suffered by his neighbours. Because "all the mouths get lost, given time," (134) he, whose mouth got lost at birth, chronicles the stories of the people "who dug a hole for themselves in that town and kept right at it digging away," (133) like Oneida's father. In fact the whole narrative appears as an extended cliché: time is a great healer. As the narrator points out, "[j] ust living long enough wipes out the problems. Puts you in a select club. No matter what your disabilities may have been [....]" (151) because, in the end, "everybody's face will have suffered, never just yours" (151). Narrating stories of failure closes the gap between the subject and the world around him: he is "like" the others, not different.

But of course below the surface of this teleological narrative, the unbridgeable gaping hole remains: there can be no true repair for the subject condemned to the evidence of his lack. There can only be patching up. Thus, a certain balance is indeed struck 
when the physically different narrator and socially different Oneida develop a form of friendship which allows them both to reproduce the gentle rituals of their lost sheltered childhoods: they meet weekly to watch television and share a meal. Yet, when the narrator becomes ill and is nursed back to health by Oneida, the old wound re-opens and the compromise can no longer hold. The delirious narrator openly regresses, throwing tantrums and re-enacting with Oneida the scenes of sadistic affective blackmail through which he controlled his guilt-ridden mother. When Oneida proposes to move in with him and live as brother and sister, the narrator, emotionally still "an unfortunate child" that only a mother could love, is deeply hurt in his masculine pride. Refusing to be "a neuter," to be castrated again and faced with his lack, he rejects her proposal violently and impulsively decides to sell his house. As they move apart, they are brought back together by chance: by an image of beauty, a typical Munrovian "queer bright moment" (Munro "Introduction," The Moons of Jupiter xv): five little skunks, "proud of themselves but discreet," "flashing and dancing" in the birdbath outside, in the garden. A perfect image of acceptance, self-acceptance, the baby skunks, proud and discreet, are the smooth doubles that allow the narrator to leave the rough solitary world of monstrosity (the monster is unique and has no other like him) and join the chain of beings. The beauty of the little white skunks, with their strip of black like a dark scar in the middle of their backs turns the narrator's ugly scar in the middle of his face into an acceptable mirror image. If there can be no happy ending, at least in the end, there is the sense of belonging to the world at large: "we were as glad as we could be" (153). "Glad," from the old high German glat, meaning smooth and shiny.

In "Train," mending the wounds mainly consists in running away, or more literally, walking away from any form of emotional closeness and intimacy: "Jumping off the train was supposed to be a cancellation. You roused your body, readied your knees, to enter a different block of air. You looked forward to emptiness" (176). The plot in fact follows the random moves and chance encounters of the protagonist, from block of air to block of air. Moving from place to place whenever he gets too close to pain, commitment or intimacy, Jackson is a typical Munrovian outsider, but unlike the narrator of "Pride" who returns obsessively to his wound and keeps digging at it, Jackson lives on the surface of things, intent not to be affected by them, which does not mean that he travels without baggage. Emotional distance and dis-affect characterise his toneless internal voice, which is never given directly, but always dis-located, elsewhere, filtered by free indirect speech. The use of a third-person narrative and frequently of the passive form, the recurrent blanks and long ellipses in the text create the sense of a character unaffected by time, by the noises of the world around him: "it seemed to have little to do with him, to be quite far away" (193). At best, he is a mere consciousness that flatly registers and records the surroundings, or a stranger that has landed in a fairy tale, as indicated by his fascination for the little Mennonites, a "half dozen little men" (180), the doubles of the seven little dwarfs of the fairy tale, singing in their cart on their way to church. Anaesthetized, his deep wound nonetheless is clearly visible, just below the surface of his "phenomenal shyness and silence" (208) and while the narrative of his life unfurls in a linear and chronological fashion, albeit punctuated by extensive gaps and long-drawn silences, an alternative, retrospective narrative emerges. Splintering the text, a drama of child abuse remains unarticulated and properly dis-located. It is displaced in the story of Belle whose overt confession of incest forces him to run away after twenty 
years of blissful oblivion, and also in the story of his failed sexual relationship with a young woman from whom he ran away in his youth. Therefore it is linked ultimately to his abusive stepmother, from whom he ran away as a very young child. In "Train," we are reminded of "The Moons of Jupiter" where the narrator is embarrassed at the sight of her father's electrocardiograph above his hospital bed: "the behaviour of his heart was on display, I tried to ignore it. It seemed to me that paying so close attention - in fact dramatizing what ought to be a most secret activity was asking for trouble" (Selected Stories 217-8). "Train" does allude to the traumatic narrative locked up in the crypt of Jackson's shyness, but economically, without dwelling on it, without dramatizing what ought to remain a most secret activity, because dramatizing is "looking for trouble." Belle's lump in her breast is the clandestine inscription of the secret locked up in her for over 40 years that she finally gets off her chest after her operation. But her secret is the festering wound that kills her because she "could not get outside the tragedy" (Dear Life 198). Jackson on the other hand got out early. He found a way to survive: "it came to him quite easily, that a person could just not be there" (214). Jumping on or off trains is a "cancellation" (176), a way to commit neither to the present nor to the future and a way to avoid confronting the consequences of one's past actions. Jackson stays out of trouble, away from emotions, outside of life, outside of language, following a logic of severance and emotional detachment. Choosing to remain on the margins of life, disowning all forms of affect and surrounded by loners and loonies, he has escaped the logic of desire and lack and thus has escaped pain.

In "Gravel," dealing with the wounds from the past is directly inscribed in the narrative situation: we have a first-person retrospective narrative, triggered by a meeting between the narrator, now an adult, and Neal, her mother's former lover, in an attempt to "rout out her demons" (106). Writing down the story of what must, might or may have happened is yet another attempt at ordering reality with words. "Must have," "might have" or "maybe" are the three modalities according to which, each in turn, the narrator's therapist, the narrator's companion and then Neal try to reconstruct the truth of what happened in the gravel pit, and thus help the subject reconstruct herself in language. But the narrator opposes a grammar of melancholy to their logic of mourning: her symptomatic use of concessive and contrastive conjunctions exposes the impossibility for her of settling down in language. "But," "however," or "although," are the symptoms of the narrator's refusal of closure, a refusal she acknowledges in the text: "The counsellor was satisfied to bring me to this conclusion, and I was satisfied too. For a while. But I no longer think that was true" (103). The constant seesaw movement of concessive and contrastive forms, of assertions and refutations is the sign of an open wound, of an impossibility to introject the loss and to accept the fact of death. Death is also suspended by the impossibility for the narrator of accepting involvement in the drama and endorsing any version of reality. Pounding the narrative, formulas like "I can't remember," "I can't imagine," and "I can't recall" hollow out the possibility of constructing a narrative of what happened. Amnesia both muddies the waters and puts the narrator in the clear. The contrapuntal dialogue - in fact an internal monologue - between the sisters in which Caro tells the young narrator what to do and the narrator puts up some argument not to follow the orders is a clear symptom of a defect of mourning. In what can be seen as a moment of ventriloquism the narrator becomes both the voice of her four-year-old self and that of her older sister, very much 
as if she had incorporated Caro, making it impossible for the reader to disentangle the two voices in the exchange:

I was to go to the trailer and tell Neal and our mother something.

That the dog had fallen into the water

The dog had fallen into the water and Caro was afraid she'd be drowned.

Blitzee. Drownded

Drowned.

But Blitzee wasn't in the water.

She could be. And Caro could jump in to save her. (102)

Impossible closure in this passage is clearly related to unresolved issues of guilt and bad faith, to natural sibling rivalry and to the rebellion, at the wrong time, of the younger sister against the authority of her elder: "Caro was afraid she'd be drowned" looms, utterly ambiguous in the text, as the probable words of Caro to her sister, but also as the secret thought of the young sister annoyed by her bossy elder's orders. Like an unclosed wound, the suggestion of the narrator's responsibility in the death of her older sister remains an open possibility, a "maybe" that, like an insistent niggling, recurrent doubt will always undermine all straightforward reconstruction of the past. Therefore the three versions of the stories she rehearses incessantly, in her mind, in her dreams and in her memory can never be reconciled, leaving her unable to exist in language other than as a sum of contradictions. Caro must remain undead and the narrator, incapable of re-membering or writing the story of how she did hear the splash that changed her life, must remain a subject in pieces stranded in a past that does not pass by.

\section{The Coda: "In Sight of the Lake" and the "Finale"}

According to Gabriele Schwab "in order for trauma to heal, body and self must be reborn and words must be disentangled from the dead bodies they are trying to hide" (95). The final section of the collection, or "finale" represents a renewed attempt at disentangling words from the bodies they are trying to hide, a conscious attempt to introject the dead, to speak about them objectively as separate entities and to bury them at last in words. In the logic of the volume, we have reached the end of the journey, figured in the texts by the various streaks of train tracks crisscrossing the Canadian landscape of Munro's fiction, like so many lines on the page and so many journeys in a mindscape. The journey through space from Vancouver to Toronto in the first story and back and forth in the mindscape/landscape of South Western Ontario necessarily leads back "home" to the childhood house "at the end of a long road" (229) in "Dear Life," the last text of the volume. There is the source, "the wound into which Munro keeps dipping her pen" in the words of Tegan Bennett Daylight (n.p.). The house is the womb of all the stories that have shaped the author throughout her career. It is the echo chamber of the stories that a mother, the first and closest storyteller, told her daughter time and time again before the tightening of the muscles in her throat stole her power of speech. The house at the end of the road is the foundation on which the house of fiction is built. And all its rooms lead to the kitchen, to the hiding place near the dumbwaiter (the place of the notorious royal beatings), in the smallest place of all: a mother's embrace of her daughter to whom she "hangs on for dear life" (318). But this tiny room of love is also the dark hole or the tomb where the myth of maternal plenitude and the daughter's infantile fantasy of a mother's omnipotence come to crash. The 
addition of autobiographical memories to the volume clearly shows what is at stake in writing fiction: to repeat in order to contain, and to remember in order to forget, forgive oneself and move on. Revisiting through memories and anecdotes the house of her childhood and the stories she grew up on, Munro makes an archaeological discovery: she unearths the figure of old Mrs. Netterfield and her "visitation." Mrs. Netterfield is the true ghost that haunts the house at the end of the long road and the house of fiction, a ghost from the past but also a prospective ghost. Her story is the story of an "old woman looking in the windows of what had been her own house" (318) for what she had lost, a daughter "grown and distant" (318). It is the story of a mother gone and become distant in her madness, but also of her daughter grown and become distant in her indifference, a daughter who, like the author, writes and publishes texts about the idyllic place of her childhood but leaves the mud out ${ }^{2}$ and leaves her mother behind, locked out of her house and locked in her dementia. Re-telling stories like that of Mrs. Netterfield's visitation makes it possible for the writer to carry on living in a world of words and doubles, containing, restraining and framing, in part, the pain of the loss of her mother and atoning in words for her guilt.

But read together with another story from the volume, the story of the visitation ultimately becomes the story of a writer, grown old now, who, in turn looks in the windows of what had been her childhood home. In "In Sight of the Lake" Nancy, a double of the author in her old age and a double of Mrs. Netterfield in her dementia, travels through an unknown town in search of a doctor. At the end of the road, she reaches a house, the Lakeview Rest Home, a poor substitute for the house at the end of the long road and a pale double of the house of fiction. We see her looking in through the lofty windows of the totally empty home, just like Mrs. Netterfield peering through the windows of her old house, only to realize that Nancy is not locked out, but locked in the space of her demented mind, where time has stopped at "twelve, for noon or midnight," (221) where, like her memory, she is condemned to err in a past that will never pass by, caught in stories that no one, not even herself, is telling. Dear Life is also about writing for dear life, about the urgency to say, again and again, and against the clock, before it stops ticking.

Christine BERTHIN University of Paris Ouest-Nanterre / CREA 370

\section{Works Cited}

Bennett Daylight, Tegan. "Still Life in the Hands of Canadian author Alice Munro." The Australian 08 Dec. 2012. http://www.theaustralian.com.au/arts/review/still-life-in-the-hands-of-canadianauthor-alice-munro/story-fn9n8gph-1226531239057. Consulted 26 March 2015.

Carrington, Ildikó de Papp. Controlling the Uncontrollable: The Fiction of Alice Munro. DeKalb: Northern Illinois UP, 1989.

Gigante, Denise. "Facing the Ugly: The Case of Frankenstein." ELH 67.2 (2000): 565-87.

Grosz, Elizabeth. Jacques Lacan: A Feminist Introduction. London: Routledge, 1990.

Hancock, Geoffrey. “An Interview with Alice Munro." Canadian Fiction Magazine 43 (1982): 74-114.

2. "She had left out, just as I would have done, the way the spring got muddied up and soiled all around by horses' hooves. And of course left out the manure.” (317) 
Munro, Alice. "What is Real?” Making it New: Contemporary Canadian Stories. Ed. John Metcalf. Auckland: Methuen, 1982. 223-6.

—. Selected Stories. London: Random House, Vintage, 1997.

-. Hateship, Friendship, Courtship, Loveship, Marriage. London: Vintage, 2001.

—. The Moons of Jupiter. London: Vintage, 2004.

—. Dear Life. London: Vintage, 2012.

Robson, Leo. "New Selected Stories by Alice Munro: Moments of wonderful soft-fingered race." New Statesman Sept. 2011. <http://www.newstatesman.com/fiction/2011/09/selected-stories-munrostory. Consulted 16 June 2014.

Rosset, Clément. Le Réel, traité de lidiotie. 1997. Paris: Editions de Minuit, 2004.

SснWAв, Gabriele. "Writing against Memory and Forgetting." Literature and Medicine 25.1 (Spring 2006): 95-121.

SMYtHe, Karen E. Figuring Grief: Gallant, Munro and the Poetics of Elegy. Montreal: McGill-Queen's UP, 1992.

ZizeK, Slavoj. Looking Awry. An Introduction to Jacques Lacan through Popular Culture. Cambridge: MIT Press, 1991.

—. "The Lamella of David Lynch." Reading Seminar XI: Lacan's Four Fundamental Concepts of Psychoanalysis. Ed. R. Feldstein, B. Fink, and M. Jaanus. Albany: SUNY P, 1995. 205-20. 